\title{
An Analysis of Operation Conditions and Microbial Characteristics in Swine Wastewater Treatment Plants with Spontaneously Enriched Anammox Bacteria
}

\author{
Miyoko Waki ${ }^{1, *}$ (]) , Chikako Ishimoto ${ }^{2}$, Ryu Suto ${ }^{3}$, Takafumi Nagamine ${ }^{4}$, Toshimi Matsumoto ${ }^{5}$, \\ Hirohide Uenishi ${ }^{5}$, Tomoko Yasuda ${ }^{1}$ and Yasuyuki Fukumoto ${ }^{1}{ }^{1}$ \\ 1 Institute of Livestock and Grassland Science, National Agriculture and Food Research Organization (NARO), \\ 2 Ikenodai, Tsukuba, Ibaraki 305-0901, Japan; tomokoya@affrc.go.jp (T.Y.); yasuyuki@affrc.go.jp (Y.F.) \\ 2 Shizuoka Prefectural Research Institute of Animal Industry Swine \& Poultry Research Center, 2780 Nishikata, \\ Kikugawa, Shizuoka 439-0037, Japan; chikako1_ishimoto@pref.shizuoka.lg.jp \\ 3 Ibaraki Prefectural Livestock Research Center, 1234 Negoya, Ishioka, Ibaraki 315-0132, Japan; \\ r.sutou@pref.ibaraki.lg.jp \\ 4 Misakura Electric Co., Ltd., 1158-11 Komatsu, Miyazaki 880-2112, Japan; takafumi_nagamine@misakura.co.jp \\ 5 Institute of Agrobiological Sciences, NARO, 1-2 Owashi, Tsukuba, Ibaraki 305-8634, Japan; \\ mtoshimi@affrc.go.jp (T.M.); huenishi@affrc.go.jp (H.U.) \\ * Correspondence: mwaki@affrc.go.jp; Tel.: +81-29-838-8677
}

\section{check for}

updates

Citation: Waki, M.; Ishimoto, C.;

Suto, R.; Nagamine, T.;

Matsumoto, T.; Uenishi, H.;

Yasuda, T.; Fukumoto, Y. An Analysis

of Operation Conditions and

Microbial Characteristics in Swine Wastewater Treatment Plants with Spontaneously Enriched Anammox Bacteria. Processes 2021, 9, 1010. https://doi.org/10.3390/pr9061010

Academic Editor: Bipro R. Dhar

Received: 12 May 2021

Accepted: 2 June 2021

Published: 7 June 2021

Publisher's Note: MDPI stays neutral with regard to jurisdictional claims in published maps and institutional affiliations.

Copyright: (c) 2021 by the authors. Licensee MDPI, Basel, Switzerland. This article is an open access article distributed under the terms and conditions of the Creative Commons Attribution (CC BY) license (https:// creativecommons.org/licenses/by/ $4.0 /)$
Abstract: The spontaneous enrichment of anammox bacteria has been reported in swine wastewater treatment facilities. However, their causative conditions and microbial characteristics, which this study aims to explain, are poorly understood. We discovered eight treatment facilities where the collected red biofilms exhibited high anammox activity levels at $57-843 \mu$ mol- $\mathrm{N}_{2} / g$-ignition loss (IL)/h and anammox DNA concentrations of $4.3 \times 10^{8}-1.6 \times 10^{12}$ copies/g-IL. The facilities used various wastewater treatment methods-six of them employed a multi-stage continuous reactor, whereas aeration tanks were continuously aerated at another combination of six facilities. Levels of dissolved oxygen (DO) in these tanks were fairly low at $\leq 1 \mathrm{mg} / \mathrm{L}$. Pyrosequencing of the biofilms indicated the presence of $3-62.5 \%$ Planctomycetes, and the dominant anammox in each biofilm comprised three operational taxonomic units (OTUs) similar to Candidatus Jettenia asiatica, $\mathrm{Ca}$. Brocadia fulgida, and $\mathrm{Ca}$. B. caroliniensis. This suggested that some particular species of anammox bacteria naturally thrive when operating a swine wastewater treatment facility at low DO levels. The frequent enrichment of anammox biofilms at the sampled sites indicated that these treatment facilities were good seed sources of anammox; therefore, anammox treatment would be a viable method for the removal of nitrogen from swine wastewater.

Keywords: activated sludge; anammox; nitrogen removal; SNAD; swine wastewater; dissolved oxygen

\section{Introduction}

Nitrogen (N) pollution in water systems due to livestock excrement has become a serious problem owing to the worldwide increase in livestock populations [1]. In Japan, pig farming, in particular, generates a large amount of wastewater containing nitrogen; therefore, an appropriate treatment method is required. The activated-sludge process is the most widely used method for wastewater treatment in swine farms in Japan. Untreated swine wastewater is a mixture of urine, feces, and service water; this is first pre-treated by removing suspended solids using screens, gravity sedimentation, or mechanical separation with chemicals, and then treated with the activated-sludge process. Various activatedsludge processes, such as a sequencing batch reactor and a single or multi-stage continuous reactor with or without a membrane, are employed. In most cases, the temperature and aeration conditions in the process are not controlled; hence, they fluctuate with time and are highly variable. Moreover, owing to the low ratio of biochemical oxygen demand 
(BOD) to $\mathrm{N}$ in the influent, $\mathrm{N}$ is inadequately removed in the activated-sludge process using traditional nitrogen removal processes, such as denitrification following nitrification, resulting in effluent containing an average total nitrogen (TN) concentration of approximately $430 \mathrm{mg} / \mathrm{L}$ [2]. Namely, nitrogen removal by the conventional process in the swine wastewater treatment process is limited; therefore, using anaerobic ammonium oxidation (anammox) technology for nitrogen removal is desirable.

Anammox is a bacterial process in which $\mathrm{NH}_{4}{ }^{+}$is oxidized to $\mathrm{N}_{2}$ with $\mathrm{NO}_{2}{ }^{-}$as an electron acceptor under strictly anaerobic conditions $[3,4]$. Compared to the conventional method-nitrification followed by denitrification-this process is a low-cost method to remove nitrogen from wastewater as anammox does not require BOD to metabolize $\mathrm{N}$ and, through partial nitrification, reduces total aeration costs. Anammox organisms were discovered in 1995 in the wastewater treatment plant (WWTP) of a baker's yeast production facility [3]. Anammox exists naturally in many ecosystems (including seas, rivers, lakes, paddy fields, and wetlands [5,6]) and also in conventional WWTPs [7], though not dominantly. Owing to glacial growth rates with a doubling time longer than a week $[8,9]$, these bacteria take a long time to reach high concentrations. Anammox sludge enrichment typically requires several months in a pilot plant. Therefore, during the start-up of a full-scale anammox reactor, maintaining the supply of anammox seed sludge is difficult [10].

However, spontaneous anammox bacteria enrichment in biofilms was recently reported at full-scale swine-wastewater activated-sludge plants at three farms in Japan [11] and two in China [12,13]. These biofilms were red in color, as is often observed in anammox sludge enriched in artificial wastewater; they also had high activity levels (up to $295 \mu \mathrm{mol} / \mathrm{g}$-IL/h) and 16S rRNA gene copy numbers (up to $1.35 \times 10^{12}$ copies $/ \mathrm{g}$-IL) [11] for anammox. The naturally enriched anammox sludge in swine farms can be used to improve nitrogen removal in the facility by customizing the operation to increase suitability. It can also be used as a seed sludge to introduce the anammox process into other farms, though this requires additional biosafety considerations. Those naturally enriched in the swine wastewater treatment process are expected to adapt more readily to other instances of the same process and hence, are considered suitable for seeding in other swine WWTPs. The naturally enriched anammox can potentially contribute to solve the treatment problems of nitrogen-containing wastewater.

These facilities include a sequencing batch reactor, a single-stage continuous reactor, a multi-stage continuous aeration tank reactor [11], and combinations of continuous aerobic and anoxic tanks $[12,13]$. Various processes are considered acceptable in the treatment of swine wastewater for the natural enrichment of anammox; however, further research is required to accurately determine suitable processes from among them. Detailed information on the process facilities that promote natural enrichment and the microbial characteristics of the biofilms is required to effectively utilize anammox cultures in swine wastewater treatment. Therefore, the survey of swine wastewater treatment facilities for spontaneously enriched anammox was expanded to an additional five farms where anammox biofilms were found. In this study, the operating conditions and microbial characteristics of eight swine wastewater treatment facilities were investigated in detail.

\section{Materials and Methods}

\subsection{Red Biofilms in Full-Scale Swine Wastewater Treatment Plants}

We investigated the anammox biofilms from eight swine farms in Ibaraki, Saitama, Shizuoka, and Miyazaki prefectures in Japan (Table 1, Figure 1). The Sai-1, Shizu-2, Shizu-3, Miya-1, and Miya-2 farms were newly discovered to have anammox biofilms during this study, while the Iba-1, Iba-2, and Shizu-1 farms were the same facilities examined in a previous study [11]. Samples were collected from all the farms in the study, except for Shizu-1; the data for this farm were the same as that used in a previous study [14]. The pre-treatment methods and types of activated-sludge processes are shown in Table 1. In some facilities, the red biofilm was found only in a few aeration tanks; therefore, data regarding the number of affected aeration tanks were also recorded in this study. Moreover, 
biofilm was present on the walls of the activated-sludge aeration tanks, in the wastewater effluent from them, and in sedimentation tanks; hence, samples were also collected from these points. Only one sample collected at Shizu-1 was washed to remove the black sludge.
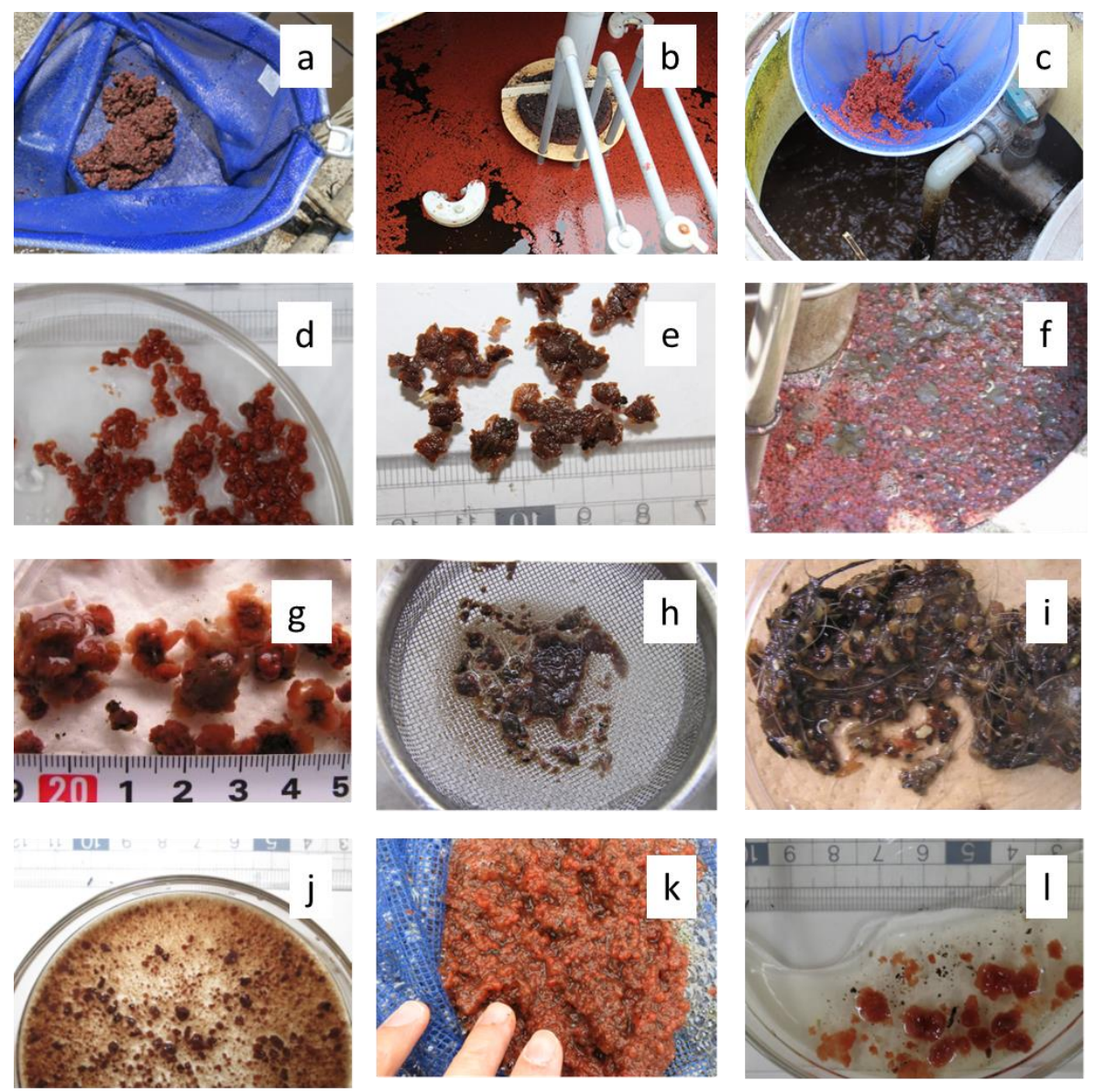

Figure 1. Biofilms collected from various tanks at the swine farms. (a) aeration tank at farm Iba-1, (b) sedimentation tank at farm Iba-2, (c,d) aeration tank at farm Iba-2, (e) aeration tank at farm Sai-1, (f) sedimentation tank at farm Shizu-1, (g) aeration tank at farm Shizu-1, (h) aeration tank at farm Shizu-2, (i) aeration tank at farm Shizu-3, (j) aeration tank at farm Miya-1, (k,1) aeration tank at farm Miya-2.

\subsection{Anammox Activity Measurement}

Samples of these biofilms were analyzed for anammox activity using the tracer incubation method $[15,16]$. The tested biofilms were then washed to remove any attached inorganic nitrogenous compounds, following which they were centrifuged and suspended in an inorganic medium. The centrifuged sludge was re-formulated to yield $100 \mathrm{mg} / \mathrm{L}$ volatile suspended sludge (VSS) or ignition loss (IL) in the medium. Ten milliliters of the suspended mixture was anaerobically batch-incubated in $25-\mathrm{mL}$ glass bottles at $25^{\circ} \mathrm{C}$; inorganic nitrogen compounds were added to these mixtures to obtain $2.5 \mathrm{mmol} / \mathrm{L}$ of ${ }^{15} \mathrm{NO}_{2}{ }^{-} /{ }^{14} \mathrm{NH}_{4}{ }^{+}$in each bottle. Anammox activity was then estimated based on ${ }^{29} \mathrm{~N}_{2}$ generation in the bottles periodically measured during the incubation period for several hours. 
Table 1. Characteristics of Facilities with Anammox Biofilms.

\begin{tabular}{|c|c|c|c|c|c|c|c|}
\hline Facility & Location & Year of Construction & Sampling Date & $\begin{array}{l}\text { Pre-Treatment Method for } \\
\text { Solid-Liquid Separation }\end{array}$ & Treatment Method & Aeration Conditions & $\begin{array}{c}\text { Aeration Tank Where } \\
\text { Anammox Biofilm Exists }\end{array}$ \\
\hline Iba-1 & Ibaraki & 1997 & 11 May 2017 & Gravity sedimentation and screening. & Sequencing batch reactor & $\begin{array}{l}\text { Intermittent (anoxic before } \\
\text { discharge) }\end{array}$ & $1 \mathrm{st}$ \\
\hline Iba-2 & Ibaraki & 2006 & 21 June 2016 & $\begin{array}{l}\text { Mechanical separation with } \\
\text { flocculating agent. }\end{array}$ & $\begin{array}{l}\text { Three-stage continuous } \\
\text { reactor and settler. }\end{array}$ & Continuous & 1st-3rd \\
\hline Sai-1 & Saitama & 2011 & 7 November 2016 & $\begin{array}{l}\text { Mechanical separation with } \\
\text { flocculating agent. }\end{array}$ & $\begin{array}{l}\text { Three-stage continuous } \\
\text { membrane reactor. }\end{array}$ & $\begin{array}{l}\text { Intermittent (1st tank), } \\
\text { continuous (2nd and } \\
\text { 3rd tanks) }\end{array}$ & $1 \mathrm{st}$ \\
\hline Shizu-1 & Shizuoka & 1989 & 12 March 2014 & Screening. & $\begin{array}{l}\text { Two-stage continuous } \\
\text { reactor and settler (with } \\
\text { activated sludge and contact } \\
\text { aeration) }\end{array}$ & Continuous & 1st, 2nd \\
\hline Shizu-2 & Shizuoka & before 1995 & 6 June 2018 & Gravity sedimentation and screening. & $\begin{array}{l}\text { Four-stage continuous } \\
\text { membrane reactor. }\end{array}$ & Continuous & 2nd \\
\hline Shizu-3 & Shizuoka & before 1995 & 14 June 2018 & Gravity sedimentation and screening. & $\begin{array}{l}\text { Two-stage continuous } \\
\text { reactor and settler. }\end{array}$ & Continuous & 1st, 2nd \\
\hline Miya-1 & Miyazaki & No data & 26 December 2018 & $\begin{array}{l}\text { Screening and mechanical separation } \\
\text { with flocculating agent. }\end{array}$ & $\begin{array}{l}\text { A continuous reactor and } \\
\text { settler. }\end{array}$ & Continuous & $1 \mathrm{st}$ \\
\hline Miya-2 & Miyazaki & No data & 8 April 2019 & $\begin{array}{l}\text { Mechanical separation with } \\
\text { flocculating agent. }\end{array}$ & $\begin{array}{l}\text { Two-stage continuous } \\
\text { reactor and settler (the first } \\
\text { aeration tank is separated } \\
\text { into three areas) }\end{array}$ & Continuous & $\begin{array}{l}\text { On the wall of the } 2 \text { nd area } \\
\text { in the 1st aeration tank }\end{array}$ \\
\hline
\end{tabular}




\subsection{Real-Time Quantitative Polymerase Chain Reaction ( $q P C R$ ) Analysis of Anammox Bacteria}

Total deoxyribonucleic acid (DNA) was extracted twice from each biofilm using FastDNA SPIN Kit for Soil (MP Biomedicals, Tokyo, Japan), bulked, and then purified with QIAEX II Gel Extraction Kit (Qiagen, Hilden, Germany). The abundance of anammox bacterial 16S rRNA genes was determined in triplicates by qPCR amplification using SsoAdvanced SYBR Green Supermix (Bio-Rad Laboratories, Hercules, CA, USA); qPCR was performed in 96-well optical plates in a real-time PCR detection system (MyiQ2 or BioRadCFX96, Bio-Rad) with the anammox-specific primer sets S-*-Amx-0368-a-A-18 and AMX820 [17] as described by Suto et al. (2017) [11].

\subsection{Pyrosequencing Analysis}

Pyrosequencing of the 16S rRNA genes was conducted as described by Ishimoto et al. (2020) [14]. These genes were amplified using the forward primer 563F and four mixed reverse primers, R1-4 [18]; the resulting amplicons were purified and paired-end sequenced on an Illumina MiSeq platform (Illumina, San Diego, CA, USA) according to standard protocols. Quality-filtered paired-end reads were then deposited in the DDBJ database under BioProject accession numbers PRJDB8118 and PRJDB8910 and BioSample accession numbers SAMD00165691, SAMD00165692, SAMD00165697-SAMD00165700, SAMD00191392, and SAMD00191393.

\subsection{Analytical Methods}

Analyses of wastewater characteristics were conducted according to standard methods at the NARO laboratory in Tsukuba (Japan). The measured parameters in liquid samples were $\mathrm{pH}$, suspended solids (SS), VSS, IL, BOD, total nitrogen (TN), ammonium $\left(\mathrm{NH}_{4}{ }^{+}\right.$), total nitrite $\left(\mathrm{NO}_{2}{ }^{-}\right)$, nitrate $\left(\mathrm{NO}_{3}{ }^{-}\right)$, and $\mathrm{DO}$ as described in the previous study [11]. Electrical conductivity (EC) was measured using an EC meter (LAQUAtwin EC-33, Horiba, Kyoto, Japan).

Furthermore, concentrations of $\mathrm{N}_{2}$ isotopomers $\left({ }^{28} \mathrm{~N}_{2},{ }^{29} \mathrm{~N}_{2}\right.$, and $\left.{ }^{30} \mathrm{~N}_{2}\right)$ produced by tracer incubation were detected by a gas chromatograph-mass spectrometer under the same conditions as Suto et al. [11].

\section{Results}

\subsection{Anammox Activity and DNA Copy Numbers in the Biofilm}

The eight biofilm samples showed anammox activity levels of $57-843 \mu$ mol- $\mathrm{N}_{2} / \mathrm{g}$ $\mathrm{IL} / \mathrm{h}$, and anammox bacterial DNA copy numbers of $4.3 \times 10^{8}-1.6 \times 10^{12}$ copies $/ \mathrm{g}$-IL (Supplementary Table S1). The anammox activity and DNA copy numbers of the biofilm and SS samples in the aeration tanks from this study and a previous study [11] (Figure 2) showed a positive correlation. Barring a few cases, both values were higher in biofilms than in the SS samples. The highest copy number $\left(1.6 \times 10^{12}\right.$ copies/g-IL) in this study was as large as that of the anammox sludge enriched in artificial wastewater $\left(6.23 \times 10^{12}\right.$ copies $/ \mathrm{g}$ volatile SS) [19]. These results showed that red biofilms contained high concentrations of living anammox bacteria.

\subsection{Facilities with Anammox Biofilms}

Anammox biofilms were observed in various types of activated treatment processes, including a sequencing batch reactor, a single continuous reactor, and six multi-stage reactors (Table 1 ). Aeration was continuous in six reactors and intermittent in two, such that the minimum duration of a single cycle of intermittent aeration was $12 \mathrm{~h}$. Membranes were used in two reactors. Pre-treatment methods included screening and mechanical separation with a flocculating agent in four facilities; the latter method causes greater declines in the SS concentration than the former owing to the flocculation process. The multistage continuous reactor and aeration tanks conspicuously occupied six facilities. In multi-stage reactors, sludge in the aeration tank moves progressively downstream; however, the biofilms tend to form on the walls of the first aeration tank. 


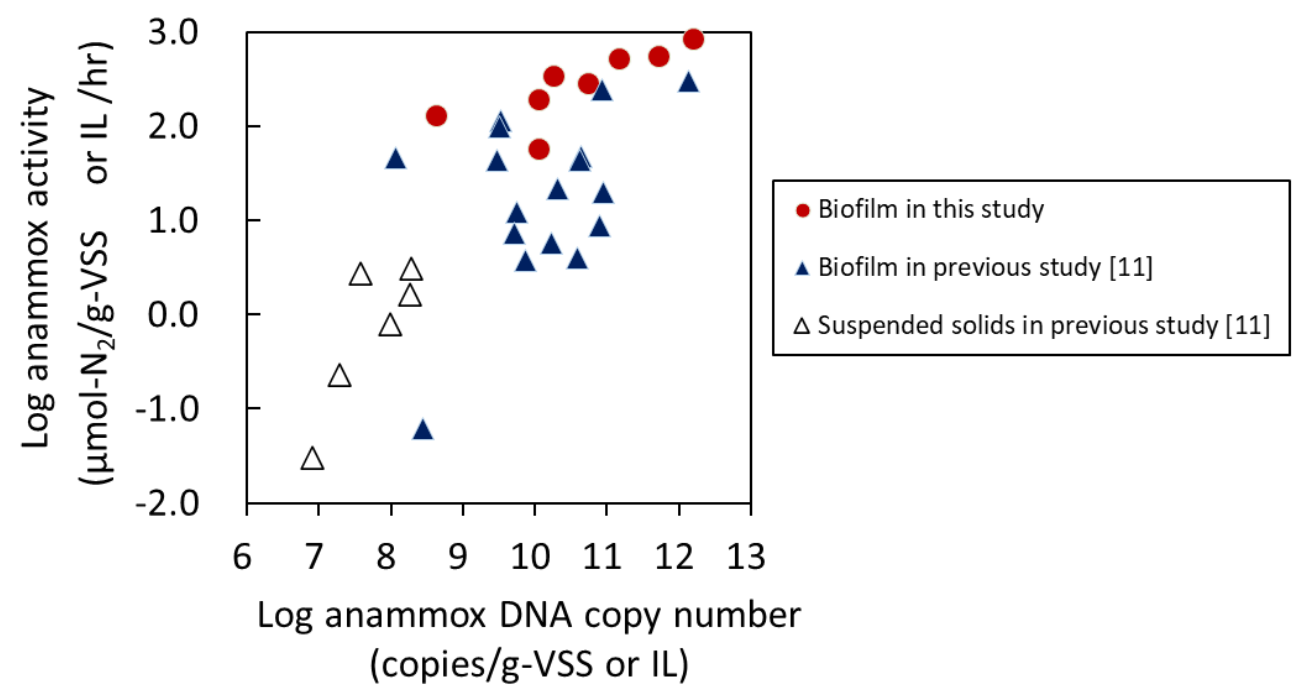

Figure 2. Relationship between anammox activity and DNA copy numbers.

As the quality of influent wastewater in livestock farms varies widely across and within the farms, the values of $\mathrm{BOD}, \mathrm{NH}_{4}{ }^{+}-\mathrm{N}$ concentration, and the $\mathrm{BOD} / \mathrm{N}$ ratio were found to vary from 400-5435 mg/L, 465-4931 mg/L, and 0.2-3.4 (Supplementary Table S2), respectively. The percentage removal of nitrogen showed wide variations, ranging from $48-99 \%$. Despite BOD/N ratios as low as 0.2 or 0.9 , some facilities exhibited adequate nitrogen removal percentages in the range of $93-98 \%$. This can likely be attributed to the contribution of anammox in nitrogen removal (Iba-1, 2 November 2014).

In most swine farms, the DO levels in the aeration tanks were not regulated with sensors and, therefore, fluctuated. However, the concentrations observed in facilities with anammox biofilms were significantly lower at values $\leq 1 \mathrm{mg} / \mathrm{L}$ (Supplementary Table S3) than those found in conventional facilities where DO concentrations ranged 0-5.8 mg/L [15].

\subsection{Microbial Characteristics of the Biofilms}

Pyrosequencing analysis of biofilms showed the phyla composition, which comprised 3-62.5\% Planctomycetes, 11-38\% Proteobacteria, and 4-31\% Chloroflexi (Figure 3a). This was in agreement with findings from previous studies, which show the Proteobacteria in the biofilm to include microorganisms with heterotrophic denitrification abilities and the Chloroflexi to scavenge organic compounds derived from anammox bacterial cells $[20,21]$.

Most species in the Planctomycetes phylum were identified as $C a$. Jettenia or Ca. Brocadia (Figure 3b). Of the Planctomycetes, 99\% were Ca. Jettenia in the sample from Shizu-1, and Ca. Brocadia in the samples from Iba-2 and Miya-2. Other samples contained $\mathrm{Ca}$. Jettenia and $\mathrm{Ca}$. Brocadia at relatively low percentages of $0.1-78 \%$ and $17-91 \%$, respectively. The remaining Planctomycetes included $0-0.8 \%$ of Brocadiaceae, while other genera accounted for $2-48 \%$ of the total Planctomycetes.

Ammonium-oxidizing bacteria and nitrite-oxidizing bacteria existed very slightly; the Nitrosomonadaceae family, which includes ammonium-oxidizing bacteria and the Nitrospira genus which are nitrite-oxidizing bacteria, were detected infrequently in the biofilm, accounting for $<1 \%$ of the total reads. This agrees with the distribution of ammonium-oxidizing bacteria in floccular fraction than in granules in nitrification-anammox reactors [22]. 

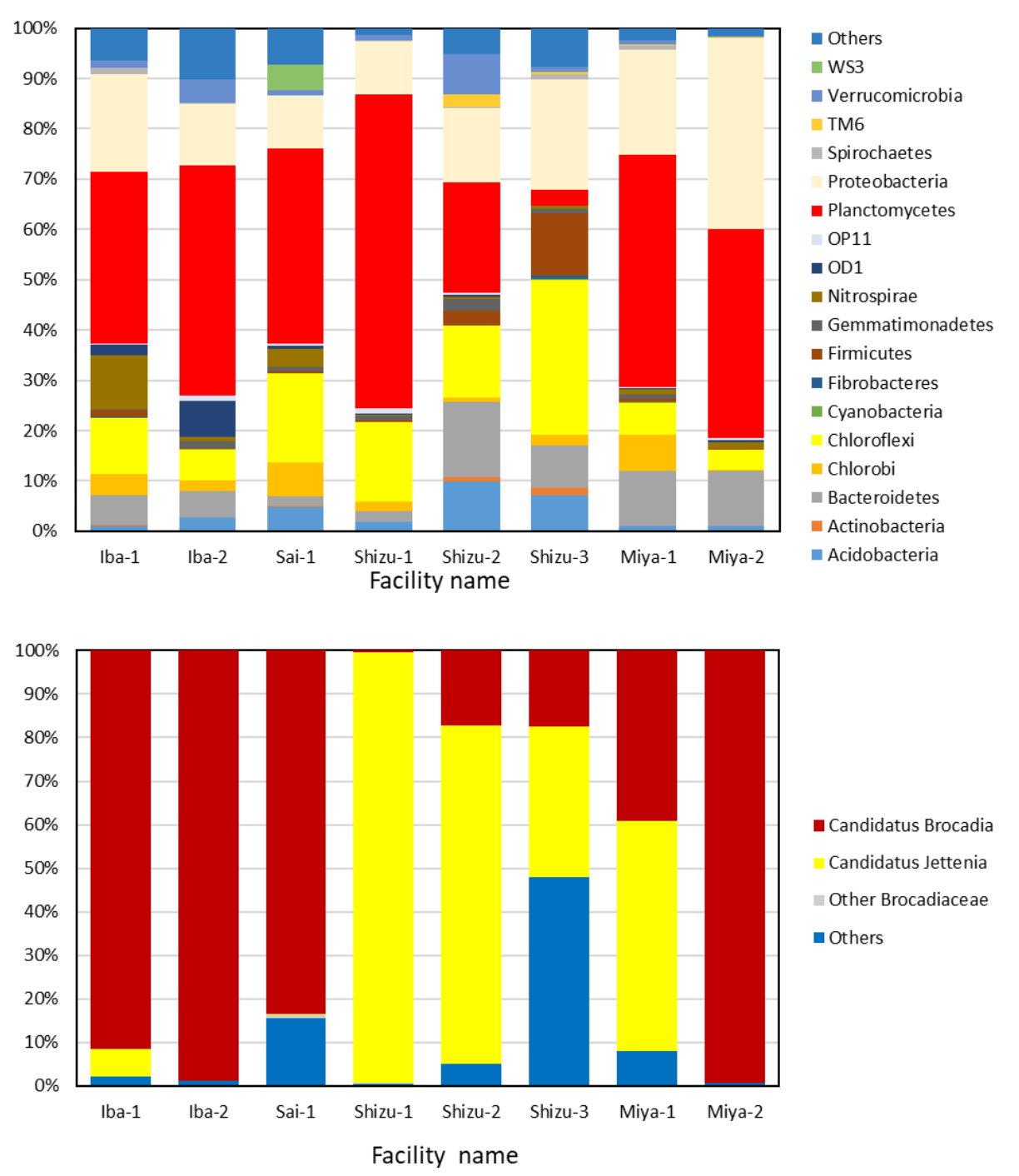

Figure 3. Relative proportions in the red anammox biofilm of: (a) the predominant bacterial phyla, (b) genera of phylum Planctomycetes. "Others" refers to phyla with $<1 \%$ abundance, genera with no known anammox bacteria, and other species from the Brocadiaceae genus.

Figure 4 shows the phylogenetic tree for the OTUs obtained from the biofilm samples, which were based on $97 \%$ sequence similarity and were affiliated with anammox. Three out of eight displayed immense similarities with known anammox species; OTU1, OTU2, and OTU3 were close to $\mathrm{Ca}$. Jettenia asiatica (DQ301513), Ca. Brocadia fulgida (DQ459989), and $\mathrm{Ca}$. B. caroliniensis (JF487828) with $99.0 \%, 99.0 \%$, and 100\% similarity, respectively. Notably, each biofilm sample included one of these three OTUs as the most dominant microbe (Table 2)-OTU1 ( $\mathrm{Ca}$. J. asiatica) corresponded to samples from Shizu-1, Shizu-2, and Miya-1; OTU2 ( $\mathrm{Ca}$. B. fulgida) to samples from Iba-1, Iba-2, and Sai-1; and OTU3 (Ca. B. caroliniensis) to samples from Miya-2. OTU3 was also relatively high in the sample from Miya-1. In Shizu-3, samples affiliated with anammox were lower among the total reads; however, its dominant microbe OTU1 possessed the highest read counts. 


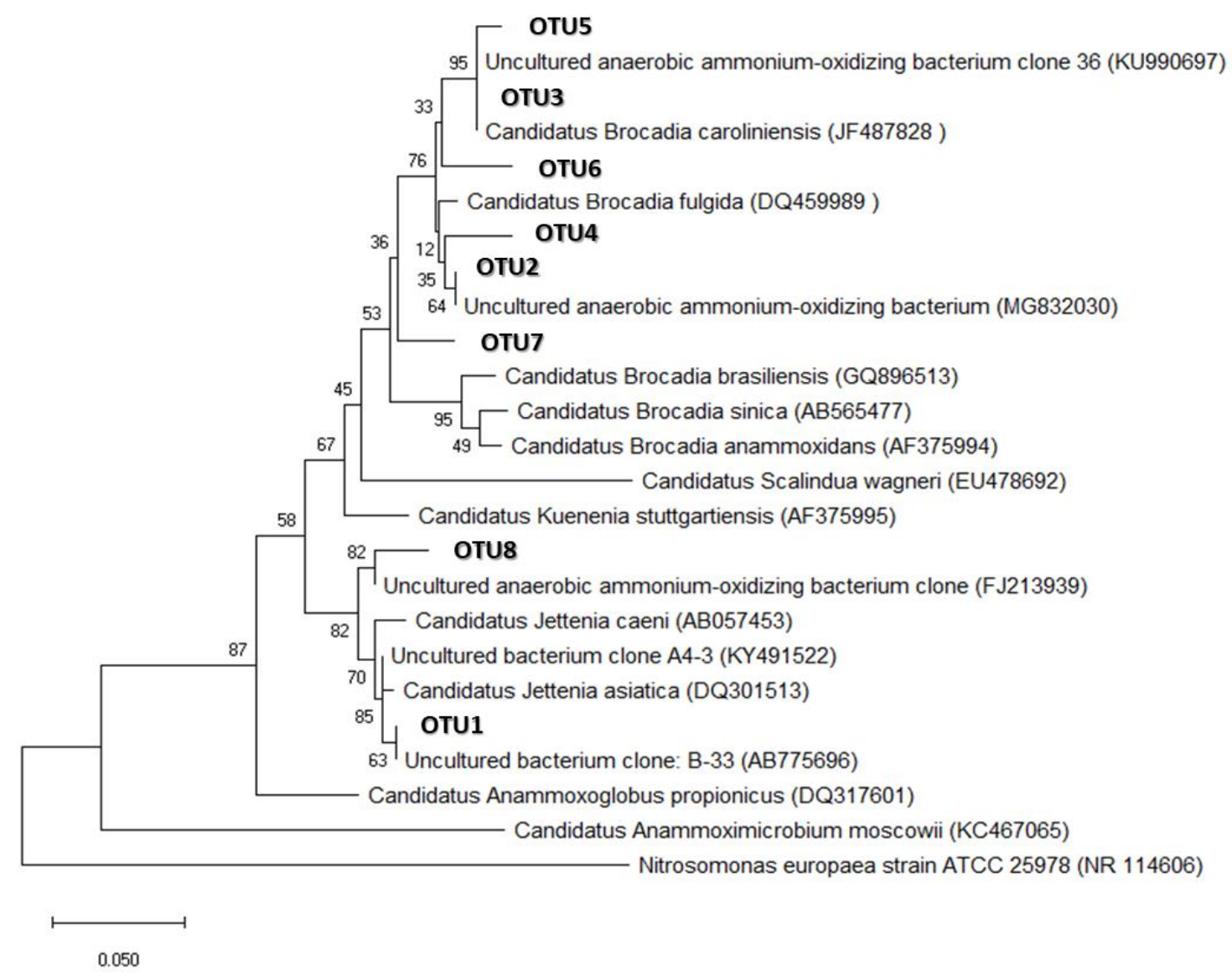

Figure 4. Phylogenetic tree of the anammox-affiliated operational taxonomic units (OTUs) occupying over $1 \%$ of the total reads.

Table 2. Proportion of operational taxonomic units (OTUs) affiliated with anammox as a percentage (\%) of the number of total reads.

\begin{tabular}{ccccccccc}
\hline Facility & OTU1 & OTU2 & OTU3 & OTU4 & OTU5 & OTU6 & OTU7 & OTU8 \\
\hline Iba-1 & 2.1 & 21.0 & $0^{*}$ & 0 & 5.2 & 2.0 & 1.4 & 0 \\
Iba-2 & 0 & 45.0 & 0 & 0 & 0 & 0 & 0 & 0 \\
Sai-1 & 0 & 32.3 & 0 & 0 & 0 & 0 & 0 & 0 \\
Shizu-1 & 61.7 & 0 & 0 & 0 & 0 & 0 & 0 & 0 \\
Shizu-2 & 14.9 & 3.7 & 0 & 0 & 0 & 0 & 0 & 1.4 \\
Shizu-3 & 1.0 & 0 & 0 & 0 & 0 & 0 & 0 & 0 \\
Miya-1 & 24.4 & 0 & 13.9 & 2.9 & 0 & 0 & 0 & 0 \\
Miya-2 & 0 & 0 & 41.1 & 0 & 0 & 0 & 0 & 0 \\
\hline * less than 1.0\% & & & & & & & &
\end{tabular}

\section{Discussion}

In Japan, swine WWTPs employ various techniques at pre-treating and at aerationtreating that constitute aeration tanks, aeration time optimization, and sludge retention. In this study, naturally enriched anammox biofilms were found at every type of treatment facility generally used in swine farms (Table 1), indicating that spontaneous anammox enrichment is not restricted to a particular type of facility. However, among the eight facilities surveyed, six included multi-stage continuous reactors, while six performed continuous aeration. Therefore, these conditions were thought to be suitable for anammox enrichment, although they also were observed in reactors including anoxic tanks in China [12,13]. The multi-stage reactor allows for different conditions in each aeration tank; reducing the 
BOD and accumulating nitrites would facilitate conditions suitable for anammox enrichment to be maintained there. The sequencing batch reactor changes the conditions in the tank, whereas the continuous reactor, which conducts continuous aeration and maintains constant conditions, would be suitable for anammox growth.

During the activated-sludge treatment process, BOD was reduced, and nitrogen was removed inside the aeration tanks (Supplementary Table S2). Simultaneous partial nitrification, anammox, and denitrification (SNAD) were observed in them [23]. SNAD progresses at low DO levels; laboratory and full-scale SNAD studies have utilized swine waste, its anaerobic digestion liquor, and other wastewaters as landfill leachate and sludge digester liquor, with the $\mathrm{DO}$ concentration set at various levels, such as below $0.5 \mathrm{mg} / \mathrm{L}$ [24], $0.3 \mathrm{mg} / \mathrm{L}$ [25], $0.3-0.5 \mathrm{mg} / \mathrm{L}$ [26], $<0.2 \mathrm{mg} / \mathrm{L}$ [12], and 0.19-0.54 mg/L [13]. A two-year study by Ishimoto et al. [14] demonstrated the importance of limiting DO levels below $0.3 \mathrm{mg} / \mathrm{L}$ among the DO fluctuations to improve nitrogen removal in the Shizu- 1 facility. Similarly, in this study, the DO levels in the aeration tank were observed to be $\leq 1 \mathrm{mg} / \mathrm{L}-$ barring one case, most of them were $<0.5 \mathrm{mg} / \mathrm{L}$. Thus, we could conclude that low DO levels in WWTPs promote the simultaneous enrichment of anammox in swine wastewater treatment facility.

The low DO levels in aeration tanks would be an indicator of the presence of naturally enriched anammox in swine WWTPs. The newest facility in this survey was constructed five years ago (Sai-1 in Table 1); however, the duration for which it has been operating at low DO levels is uncertain. Nitrogen removal by the SNAD process under low DO concentration is thought to occur due to the following reason. In most cases, ammonium oxidizing bacteria have higher oxygen affinity than nitrite-oxidizing bacteria; therefore, the low DO condition carries partial nitrification [27]. Anammox and denitrification prefer anoxic conditions; however, they would function at low DO concentration, especially in biofilm. Even if anammox enrichment does not occur in the facility, continuous aeration at low DO levels can effectively remove nitrogen from wastewater by shortcut nitrificationdenitrification pathway via nitrite [28]. This carries effective nitrogen removal at a low $\mathrm{BOD} / \mathrm{N}$ ratio and supplies substrate as nitrite for anammox. Therefore, low DO levels are recommended for the treatment of swine wastewater to enable the effective removal of nitrogen by conventional nitrification-denitrification and SNAD; this would also be accompanied by anammox enrichment. Since anammox is ubiquitous in conventional WWTP, although in a very low concentration [7], it is expected that prolonged maintenance of operating tanks at low DO levels enables the spontaneous enrichment of anammox in swine farms. However, this requires further investigation for confirmation.

Moreover, in this study, anammox biofilm was observed on the walls of the aeration tanks sedimentation tanks and as floating granules peeled from there. In these facilities, the equipment used to hold biofilm has not been installed. Therefore, nitrogen removal would be improved by maintaining low DO concentration in the aeration tanks and keeping the biofilm in the aeration tank using some devices like hydrocyclone [29] or carrier materials [12,13].

Resulting from SNAD processes, $\mathrm{Ca}$. Kuenenia stuttgartiensis, $\mathrm{Ca}$. B. caroliniensis, and $\mathrm{Ca}$. B. fulgida were reported as the dominant anammox species [30,31]. In this study, Ca. B. caroliniensis, Ca. B. fulgida, and Ca. J. asiatica predominated the biofilm (Figure 4, Table 2). This agrees with previous suggestions that the growth of $\mathrm{Ca}$. Kuenenia stuttgartiensis could be inhibited by the chemical oxygen demand (COD) of the SNAD process [30], and that conditions were more conducive to the growth of $\mathrm{Ca}$. Brocadia in the biofilm than that of $\mathrm{Ca}$. Kuenenia [32]. Ca. Brocadia was observed in various anammox reactors, while $\mathrm{Ca}$. Jettenia was not as prevalent [21]. One common feature among the three species observed in this study was their ability to utilize organic compounds. For example, $\mathrm{Ca}$. B. caroliniensis was spontaneously enriched in a full-scale glycerol-fed digester liquid treatment plant; therefore, it is suggested to have the potential for glycerol utilization [33]. $\mathrm{Ca}$. B. flugida showed enrichment in the presence of acetate and outperformed other anammox bacteria ( $\mathrm{Ca}$. B. anammoxidans and $\mathrm{Ca}$. Kuenenia stuttgartiensis) in terms of 
oxidizing formate, acetate, and propionate compounds [34]. Ca. J. asiatica predominated in a granule-treated effluent from an anaerobic reactor with a low COD concentration [35], and uptake of acetate and propionate compounds occurred [36]. The presence of organic compounds (such as short-chain fatty acids) in specific concentrations could lead to the predomination of certain anammox bacterial species over others. Anammox is versatile not only as a means of metabolizing organic compounds but also in terms of its dissimilatory reduction of nitrates to ammonium [33], which is very useful when conducting swine wastewater treatment.

Possible factors impacting the distribution of these three species are discussed in this paragraph. Iba-1, Iba-2, and Sai-1, where $\mathrm{Ca}$. B. fulgida was predominant, are located in eastern Japan and include two intermittent aeration processes (Table 1); Shizu-1-3, where $\mathrm{Ca}$. J. asiatica was predominant, is located in central Japan and uses pre-treatment system without flocculating agents, while Miya-1 and Miya-2, with a relatively high proportion of $C a$. B. caroliniensis, are located in southern Japan and use pre-treatment systems with flocculating agents. Therefore, aeration processes and pre-treatment methods that affect the BOD of the influent might be two of the determining factors. Since the influent wastewater pre-treated without using a flocculating agent tends to have higher BOD concentrations than that pre-treated with a flocculating agent, $\mathrm{Ca}$. J. asiatica possibly has better chances of survival than $\mathrm{Ca}$. Brocadia during BOD stress. This finding is consistent with the study by Chini et al. [37], which showed a shift from $\mathrm{Ca}$. Brocadia to $\mathrm{Ca}$. Jettenia with an increase in organic carbon concentration in the influent during the treatment of artificial wastewater or digestate from swine sludge. Additionally, biofilm samples from Shizu-1, where $C a$. J. asiatica (OTU1) was observed to be the predominant species in this study, had Ca. Brocadia as the predominant microbe in October 2014 [11]. Therefore, the distribution of these three species might depend on the sampling site, operating condition, or temperature, and requires further investigation.

\section{Conclusions}

Spontaneously enriched anammox biofilms were found in conventional activatedsludge facilities at eight swine farms in Japan. Although various types of wastewater treatment methods had been employed in these facilities, continuous aeration in multistage continuous reactors at low DO levels under $0.5 \mathrm{mg} / \mathrm{L}$ were the most common. Three anammox species-Ca. J. asiatica, $\mathrm{Ca}$. B. fulgida, and $\mathrm{Ca}$. B. caroliniensis-proliferated in these biofilms. This study showed the occurrence of such biofilms to be increasing in frequency in swine WWTPs and the growth and predominance of the specific bacterial species in them. Swine WWTPs may be utilized as an optimal seed source of anammox bacteria, and anammox treatment would be an effective and inexpensive option for nitrogen removal from swine wastewater.

Supplementary Materials: The following are available online at https:/ /www.mdpi.com/article/10.3 390/pr9061010/s1, Table S1: Anammox activity and deoxyribonucleic acid (DNA) copy number for each biofilm sample, Table S2: Water characteristics of influent (inf) and effluent (eff) samples investigated in the facilities, Table S3: DO concentrations in aeration tanks on the investigated facilities.

Author Contributions: Conceptualization, M.W. and C.I.; Methodology, M.W., T.M., H.U., and T.Y.; Investigation \& Resources, M.W., C.I., R.S., T.N., and Y.F.; Writing—Original Draft Preparation, M.W.; Writing-Review \& Editing, C.I., T.Y., Y.F.; Project Administration, M.W.; Funding Acquisition, M.W. and C.I. All authors have read and agreed to the published version of the manuscript.

Funding: This research was funded by the Project of the NARO Bio-oriented Technology Research Advancement Institution (Research program on the development of innovative technology, 28008A, AB) and Shizuoka Prefectural Independent Project (2018-2020).

Acknowledgments: We thank Kenji Furukawa of Kumamoto University for providing advice and encouragement, Noriko Akasaka and Tomoko Endo (NARO) for their skillful assistance, and Yoshito Aihara, Nori Miyashita (Ibaraki Prefectural Livestock Research Center, Japan), Hiroaki Saito and Hiroki Yokoshima (Yoshimoto Agri Co., Ltd., Japan) for assisting with sample collection. 
Conflicts of Interest: The authors declare no conflict of interest.

\section{References}

1. Bouwman, L.; Goldewijk, K.K.; Van Der Hoek, K.W.; Beusen, A.H.; Van Vuuren, D.P.; Willems, J.; Rufino, M.C.; Stehfest, E. Exploring global changes in nitrogen and phosphorus cycles in agriculture induced by livestock production over the 1900-2050 period. Proc. Natl. Acad. Sci. USA 2013, 110, 20882-20887. [CrossRef]

2. Waki, M.; Yasuda, T.; Fukumoto, Y.; Kuroda, A.K.; Sakai, T.; Suzuki, N.; Suzuki, R.; Matsuba, K.; Suzuki, K. Nitrogen concentrations of activated sludge process effluent of swine wastewater. J. Jpn. Soc. Water Environ. 2010, 33, 33-39. (In Japanese) [CrossRef]

3. Mulder, A.; van de Graaf, A.A.; Robertson, L.A.; Kuenen, J.G. Anaerobic ammonium oxidation discovered in a denitrifying fluidized-bed reactor. FEMS Microbiol. Ecol. 1995, 16, 177-183. [CrossRef]

4. Strous, M.; VanGerven, E.; Zheng, P.; Kuenen, J.G.; Jetten, M.S.M. Ammonium removal from concentrated waste streams with the anaerobic ammonium oxidation (anammox) process in different reactor configurations. Water Res. 1997, 31, 1955-1962. [CrossRef]

5. Zhu, G.B.; Jetten, M.S.M.; Kuschk, P.; Ettwig, K.F.; Yin, C.Q. Potential roles of anaerobic ammonium and methane oxidation in the nitrogen cycle of wetland ecosystems. Appl. Microbiol. Biotechnol. 2010, 86, 1043-1055. [CrossRef] [PubMed]

6. Zhu, G.; Wang, S.; Wang, Y.; Wang, C.; Risgaard-Petersen, N.; Jetten, M.S.; Yin, C. Anaerobic ammonia oxidation in a fertilized paddy soil. ISME J. 2011, 5, 1905-1912. [CrossRef]

7. Tsushima, I.; Ogasawara, Y.; Kindaichi, T.; Satoh, H.; Okabe, S. Development of high-rate anaerobic ammonium-oxidizing (anammox) biofilm reactors. Water Res. 2007, 41, 1623-1634. [CrossRef]

8. Strous, M.; Heijnen, J.J.; Kuenen, J.G.; Jetten, M.S.M. The sequencing batch reactor as a powerful tool for the study of slowly growing anaerobic ammonium-oxidizing microorganisms. Appl. Microbiol. Biotechnol. 1998, 50, 589-596. [CrossRef]

9. Yasuda, T.; Waki, M.; Yoshinaga, I.; Amano, T.; Suzuki, K.; Tanaka, Y.; Yamagishi, T.; Suwa, Y. Evidence of exponential growth of an anammox population in an anaerobic batch culture. Microbes Environ. 2011, 26, 266-269. [CrossRef] [PubMed]

10. van der Star, W.R.L.; Abma, W.R.; Blommers, D.; Mulder, J.W.; Tokutomi, T.; Strous, M.; Picioreanu, C.; Van Loosdrecht, M.C.M. Startup of reactors for anoxic ammonium oxidation: Experiences from the first full-scale anammox reactor in Rotterdam. Water Res. 2007, 41, 4149-4163. [CrossRef]

11. Suto, R.; Ishimoto, C.; Chikyu, M.; Aihara, Y.; Matsumoto, T.; Uenishi, H.; Yasuda, T.; Fukumoto, Y.; Waki, M. Anammox biofilm in activated sludge swine wastewater treatment plants. Chemosphere 2017, 167, 300-307. [CrossRef] [PubMed]

12. Wang, X.J.; Yang, R.L.; Zhang, Z.J.; Wu, J.B.; Chen, S.H. Mass balance and bacterial characteristics in an in-situ full-scale swine wastewater treatment system occurring anammox process. Bioresour. Technol. 2019, 292. [CrossRef] [PubMed]

13. Pan, Z.; Dai, R.; Liao, J.; Lin, J.-G.; Hong, Y.; Ling, J.; Xu, Y.; Li, Y.; Peng, J. Spontaneous formation and mechanism of anaerobic ammonium oxidation (anammox) bacteria in swine wastewater treatment system. Int. Biodeterior. Biodegrad. 2020, 154, 105058. [CrossRef]

14. Ishimoto, C.; Sugiyama, T.; Matsumoto, T.; Uenishi, H.; Fukumoto, Y.; Waki, M. Full-scale simultaneous partial nitrification, anammox, and denitrification process for treating swine-wastewater. Water Sci. Technol. 2020, 81, 456-465. [CrossRef]

15. Waki, M.; Yasuda, T.; Suzuki, K.; Sakai, T.; Suzuki, N.; Suzuki, R.; Matsuba, K.; Yokoyama, H.; Ogino, A.; Tanaka, Y.; et al. Rate determination and distribution of anammox activity in activated sludge treating swine wastewater. Bioresour. Technol. 2010, 101, 2685-2690. [CrossRef]

16. Yoshinaga, I.; Amano, T.; Yamagishi, T.; Okada, K.; Ueda, S.; Sako, Y.; Suwa, Y. Distribution and diversity of anaerobic ammonium oxidation (anammox) bacteria in the sediment of a eutrophic freshwater lake, Lake Kitaura, Japan. Microbes Environ. 2011, 26, 189-197. [CrossRef]

17. Schmid, M.C.; Maas, B.; Dapena, A.; de Pas-Schoonen, K.V.; de Vossenberg, J.V.; Kartal, B.; van Niftrik, L.; Schmidt, I.; Cirpus, I.; Kuenen, J.G.; et al. Biomarkers for in situ detection of anaerobic ammonium-oxidizing (anammox) bacteria. Appl. Environ. Microbiol. 2005, 71, 1677-1684. [CrossRef]

18. Zhang, T.; Shao, M.-F.; Ye, L. 454 Pyrosequencing reveals bacterial diversity of activated sludge from 14 sewage treatment plants. ISME J. 2012, 6, 1137-1147. [CrossRef]

19. Bae, H.; Park, K.-S.; Chung, Y.-C.; Jung, J.-Y. Distribution of anammox bacteria in domestic WWTPs and their enrichments evaluated by real-time quantitative PCR. Process Biochem. 2010, 45, 323-334. [CrossRef]

20. Kindaichi, T.; Yuri, S.; Ozaki, N.; Ohashi, A. Ecophysiological role and function of uncultured Chloroflexi in an anammox reactor. Water Sci. Technol. 2012, 66, 2556-2561. [CrossRef]

21. Pereira, A.D.; Cabezas, A.; Etchebehere, C.; Chernicharo, C.A.d.L.; de Araújo, J.C. Microbial communities in anammox reactors: A review. Environ. Technol. Rev. 2017, 6, 74-93. [CrossRef]

22. Shi, Y.; Wells, G.; Morgenroth, E. Microbial activity balance in size fractionated suspended growth biomass from full-scale sidestream combined nitritation-anammox reactors. Bioresour. Technol. 2016, 218, 38-45. [CrossRef] [PubMed]

23. Chen, H.H.; Liu, S.T.; Yang, F.L.; Xue, Y.; Wang, T. The development of simultaneous partial nitrification, ANAMMOX and denitrification (SNAD) process in a single reactor for nitrogen removal. Bioresour. Technol. 2009, 100, 1548-1554. [CrossRef]

24. Daverey, A.; Hung, N.-T.; Dutta, K.; Lin, J.-G. Ambient temperature SNAD process treating anaerobic digester liquor of swine wastewater. Bioresour. Technol. 2013, 141, 191-198. [CrossRef] 
25. Wang, C.C.; Lee, P.H.; Kumar, M.; Huang, Y.T.; Sung, S.W.; Lin, J.G. Simultaneous partial nitrification, anaerobic ammonium oxidation and denitrification (SNAD) in a full-scale landfill-leachate treatment plant. J. Hazard. Mater. 2010, 175, 622-628. [CrossRef] [PubMed]

26. Xu, X.; Wang, G.; Zhou, L.; Yu, H.; Yang, F. Start-up of a full-scale SNAD-MBBR process for treating sludge digester liquor. Chem. Eng. J. 2018, 343, 477-483. [CrossRef]

27. Li, J.; Li, J.; Gao, R.; Wang, M.; Yang, L.; Wang, X.; Zhang, L.; Peng, Y. A Critical Review of One-stage Anammox Processes for Treating Industrial Wastewater: Optimization Strategies Based on Key Functional Microorganisms. Bioresour. Technol. 2018, 265, 498-505. [CrossRef] [PubMed]

28. Waki, M.; Yasuda, T.; Fukumoto, Y.; Béline, F.; Magrí, A. Treatment of swine wastewater in continuous activated sludge systems under different dissolved oxygen conditions: Reactor operation and evaluation using modelling. Bioresour. Technol. 2018, 250, 574-582. [CrossRef]

29. Wett, B.; Hell, M.; Nyhuis, G.; Puempel, T.; Takacs, I.; Murthy, S. Syntrophy of aerobic and anaerobic ammonia oxidisers. Water Sci. Technol. 2010, 61, 1915-1922. [CrossRef]

30. Zhang, X.; Zhang, H.; Ye, C.; Wei, M.; Du, J. Effect of COD/N ratio on nitrogen removal and microbial communities of CANON process in membrane bioreactors. Bioresour. Technol. 2015, 189, 302-308. [CrossRef]

31. Zheng, Z.; Li, J.; Ma, J.; Du, J.; Bian, W.; Li, Y.; Zhang, Y.; Zhao, B. Nitrogen removal via simultaneous partial nitrification, anammox and denitrification (SNAD) process under high DO condition. Biodegradation 2016, 27, 195-208. [CrossRef]

32. Zheng, B.; Zhang, L.; Guo, J.; Zhang, S.; Yang, A.; Peng, Y. Suspended sludge and biofilm shaped different anammox communities in two pilot-scale one-stage anammox reactors. Bioresour. Technol. 2016, 211, 273-279. [CrossRef] [PubMed]

33. Park, H.; Brotto, A.C.; van Loosdrecht, M.C.M.; Chandran, K. Discovery and metagenomic analysis of an anammox bacterial enrichment related to Candidatus "Brocadia caroliniensis" in a full-scale glycerol-fed nitritation-denitritation separate centrate treatment process. Water Res. 2017, 111, 265-273. [CrossRef]

34. Kartal, B.; Van Niftrik, L.; Rattray, J.; Van De Vossenberg, J.L.; Schmid, M.C.; Sinninghe Damsté, J.; Jetten, M.S.; Strous, M. Candidatu s 'Brocadia fulgida': An autofluorescent anaerobic ammonium oxidizing bacterium. FEMS Microbiol. Ecol. 2008, 63, 46-55. [CrossRef] [PubMed]

35. Li, X.J.; Sun, S.; Yuan, H.Y.; Badgley, B.D.; He, Z. Mainstream upflow nitritation-anammox system with hybrid anaerobic pretreatment: Long-term performance and microbial community dynamics. Water Res. 2017, 125, 298-308. [CrossRef] [PubMed]

36. Tao, Y.; Huang, X.L.; Gao, D.W.; Wang, X.L.; Chen, C.H.; Liang, H.; van Loosdrecht, M.C.M. NanoSIMS reveals unusual enrichment of acetate and propionate by an anammox consortium dominated by jettenia asiatica. Water Res. 2019, 159, 223-232. [CrossRef] [PubMed]

37. Chini, A.; Bolsan, A.C.; Hollas, C.E.; Antes, F.G.; Fongaro, G.; Treichel, H.; Kunz, A. Evaluation of deammonification reactor performance and microrganisms community during treatment of digestate from swine sludge CSTR biodigester. J. Environ. Manag. 2019, 246, 19-26. [CrossRef] [PubMed] 